\title{
The gene encoding ARS-binding factor I is essential for the viability of yeast
}

\author{
Peter R. Rhode, Kevin S. Sweder, ${ }^{1}$ Karen F. Oegema, and Judith L. Campbell \\ Divisions of Chemistry and Biology, California Institute of Technology, Pasadena, California 91125 USA
}

\begin{abstract}
The gene encoding a yeast ARS-binding protein, ABF I, has been cloned by screening a genomic $\lambda$ gt11 library using monoclonal and polyclonal antibodies against ABF I. ABF I is of interest because it not only binds to ARSs but also to the $5^{\prime}$-flanking region of genes encoding proteins involved in transcription, translation, respiration, and cell-cycle control. The cloned gene has been used to prepare null mutants, which further demonstrate the importance of the ABF I protein by showing that it is essential for vegetative growth. ABF1 maps to chromosome V. The DNA sequence of the ABF1 gene reveals several motifs characteristic of DNAbinding proteins but shows no overall similarity to any protein of known function.
\end{abstract}

[Key Words: DNA-binding proteins; DNA replication; ribosomal protein genes; mitochondrial proteins genes; $H M R$ E silencer]

Received August 25, 1989; revised version accepted October 3, 1989.

Eukaryotic DNA replication initiates at multiple sites within the chromosome during the $\mathrm{S}$ phase of the cell cycle. In yeast, replication is thought to initiate at specific origins corresponding to autonomously replicating sequences (ARSs), which are operationally defined as DNA elements that allow extrachromosomal maintenance of plasmid DNAs. Physical mapping of replication intermediates formed in vivo and in vitro demonstrate that ARSs serve as origins of replication both on plasmids and in the chromosome, validating the usefulness of ARS elements in experimentally examining the initiation of chromosomal replication (for review, see Newlon 1989).

Mutational analysis of a number of ARSs has indicated that sequences required for ARS function are complex. ARS1 consists of three functional domains: A, B, and $C$ (Celniker et al. 1984). Domain A contains the 11-bp core consensus sequence (A/T TTTATRTTT A/T) ( $R=$ A or G) found at all ARSs (Stinchcomb et al. 1981; Broach et al. 1983|. Point mutations in the core consensus cause a complete loss of ARS function, defining domain A as essential (see Celniker et al. 1984; Kearsey 1984) for the HO ARS. Domains B and C flank domain A on either side. Domain B consists of $\sim 110$ bp of DNA (Srienc et al. 1985). Deletion analysis suggests that domain $B$ consists of multiple functional elements that are important, though not essential, for ARS function (Srienc et al. 1985; Snyder et al. 1987; Diffley and Stillman 1988; Strich et al. 1988). This domain contains many features that may contribute to optimal ARS function: regions of bent DNA, AT-rich DNA, DNA

'Present address: Department of Biology, Stanford University, Stanford, California 94305 USA. that unwinds relatively easily, a sequence conserved among many ARSs, and multiple copies of close matches to the core consensus (Broach et al. 1983; Palzkill et al. 1986; Snyder et al. 1987; Umek and Kowalski 1987; Palzkill and Newlon 1988; Williams et al. 1988). Domain C, $\sim 200 \mathrm{bp}$ in size, has been shown by deletion analysis to be less important than domain B for ARS function (Celniker et al. 1984; Koshland et al. 1985; Srienc et al. 1985). One functional model for ARS1 describes domain $\mathrm{A}$ as an initiation protein recognition site analogous to the 9-bp dnaA protein recognition site at oriC of Escherichia coli. Domain B may contain sequences required for efficient assembly of the initiation complex, for DNA unwinding, or for transcriptional activation of the origin. The function of domain $\mathrm{C}$ is presently unknown. On the basis of prokaryotic and viral replication origins, it is reasonable to assume that proteins that bind to these functional domains will be involved in initiating and regulating DNA replication.

Several laboratories have detected an activity that specifically binds to a site in domain B shown by deletion analysis to be important for optimal ARS activity (Shore et al. 1987; Buchman et al. 1988a; Diffley and Stillman 1988; Sweder et al. 1988). This activity, ARS-binding factor I (ABF I) or silencer-binding factor B (SBF-B), also binds to sequences adjacent to at least five other ARSs, including the ARS at the silent mating-type locus, $H M R$ $E$ (Shore et al. 1987; Buchman et al. 1988a; Diffley and Stillman 1988; Sweder et al. 1988). ARSs associated with $H 2 B, H 4, H M L E$ did not compete for ABF I binding to $H M R E$ (Buchman et al. 1988a). Given the sensitivity of the assay, this suggests that $A B F$ I has an affinity at least fivefold lower for these ARSs than for $H M R E$, if it binds at all. Detailed analysis of $H M R E$ function indicated 
that the ABF I-binding site is involved in transcriptional repression of $H M R$, along with maintenance and centromere-independent segregation of the $H M R$ E-bearing plasmids (Abraham et al. 1984; Feldman et al. 1984; Brand et al. 1985, 1987; Shore et al. 1987; Kimmerly and Rine 1987; Kimmerly et al. 1988). The ABF I-binding site could also activate transcription from the CYC1 promoter, suggesting that ABF I has multiple roles in transcription and replication (Brand et al. 1987). Recently, the interaction of another DNA-binding protein, OBF1, with telomeric ARS elements and a single-copy ARS (ARS121) has been characterized independently (Eisenberg et al. 1988; Francesconi and Eisenberg 1989). Sitedirected mutagenesis of ARS121 demonstrated a correlation between OBF1 binding in vitro and the ability of this ARS to function efficiently in vivo /Walker et al. 1989|. OBF1 binds the same sites in ARS1 and HMR $E$ as ABF I (Francesconi and Eisenberg 1989), suggesting that these factors are identical.

Although ABF I binds to multiple ARSs, suggesting a role in ARS function, ABF I binding is not limited to ARSs. The ABF I-binding site has been identified as a protein recognition site in the $5^{\prime}$-flanking regions of a number of genes. The common thread linking these genes is that RNA polymerase, ribosomal proteins, components of the respiratory chain, and glycolytic enzymes are all proteins involved in cell growth (for specific citations, see Discussion). In this respect, ABF I resembles only one other known transcription factor, RAP I (Shore and Nasmyth 1987; Buchman et al. 1988b; Kimmerly et al. 1988). These findings suggest that ABF I may function in coordinating DNA replication with the expression of these genes under varying growth conditions. Comparison of a number of ABF I-binding sites $(\sim 18)$ has revealed the sequence 5'-RTCRYNNNNNACG-3' ( $R=A$ or $G, Y=C$ or $T ; N$ is any nucleotide) as the consensus for high-affinity recognition by ABF I (Dorsman et al. 1989).

We have recently reported the purification of ABF I to homogeneity (Sweder et al. 1988). In this paper we used antibodies directed against this protein to isolate the $A B F 1$ gene from a $\lambda$ gt11 genomic library. The authenticity of the cloned gene was verified by overproduction of ABF I-binding activity in yeast. Examination of the $\mathrm{ABF} I$ amino acid sequence revealed several features that are similar to those found in other DNA-binding proteins, including a putative zinc finger motif. We demonstrate that the $A B F 1$ gene is essential and propose several models to explain the multiple roles of ABF I in regulating replication and transcription.

\section{Results}

\section{Characterization of anti-ABF I antibodies}

ABF I was purified to homogeneity by conventional and oligonucleotide-affinity chromatography and was used to generate rabbit polyclonal antiserum and mouse monoclonal antibodies (see Materials and methods). The specificity of these antibodies was determined by pro- tein blotting, using a partially purified fraction of yeast DNA-binding proteins. As can be seen in Figure 1A, the antibodies recognized two proteins of apparent molecular masses of 130 and $135 \mathrm{kD}$. These proteins comigrate with the silver-stained doublet observed in purified ABF I preparations and the ARS1 DNA-binding activities detected in Southwestern analysis (Sweder et al. 1988). Subsequent experiments indicated that the rabbit antisera reacted with several other polypeptides in crude yeast extracts (data not shown); however, the monoclonal antibodies detected only ABF I (e.g., see Fig. 5A, below). To confirm that these antibodies reacted with authentic $\mathrm{ABF}$ I, we tested the effects of the antibodies on the electrophoretic mobility of ABF I/ARS1 DNA complexes in nondenaturing polyacrylamide gels (Fig. 1B). Addition of rabbit antisera to the binding reaction caused a significant decrease in the mobility of the ABF I/DNA complex (lane 4), whereas preimmune serum had no effect (lane 3). No complexes were observed if ABF I was omitted from the binding reaction (data not shown). The change in mobility reflects the interaction of the antiserum with ABF I. Similarly, all six of the monoclonal antibodies tested decreased the mobility of the ABF I/DNA complex (lane 7 shows one example). These results indicate that these antibodies react with ABF I in such a way that DNA binding is not disrupted.

\section{Cloning of the ABF1 gene}

To isolate the $A B F 1$ gene, we screened a $\lambda$ gt11 yeast genomic library with the polyclonal and monoclonal antibodies described above. Initially, $1.2 \times 10^{6}$ phage were screened with rabbit polyclonal antisera, resulting in 10 positive clones. These clones were grouped into six different classes by cross hybridization and restriction enzyme mapping. Because the antiserum used in the initial screen reacts with several yeast polypeptides in addition to ABF I, it was expected that several different genes would be isolated. Each class of insert was screened with an ABF I-specific monoclonal antibody (6C11G4), and only one class gave positive signals. One clone in this class, $\lambda$ gt11-15a, contains the 4.4-kb EcoRI yeast DNA insert shown in Figure 2. Preliminary gene mapping experiments suggested that this DNA fragment did not contain the entire $A B F 1$ gene. To obtain the intact $A B F 1$ gene, we used the $\lambda$ gt11-15a insert as a hybridization probe to screen a yeast genomic library prepared in the high copy number plasmid YEp24. Yeast DNA inserts from several positive clones were found by restriction mapping to overlap the $\lambda$ gt11-15a insert. The largest yeast DNA inserts (from YEp24-3a and YEp24-4c) were found to contain the intact $A B F 1$ gene and were used to derive the restriction map shown in Figure 2.

\section{Characterization of the ABF1 gene}

Two independent methods were used to map the location of the $A B F 1$ gene within the cloned inserts and to determine the direction of transcription of the putative $A B F 1$ gene. In the first approach, Northern blots of yeast 


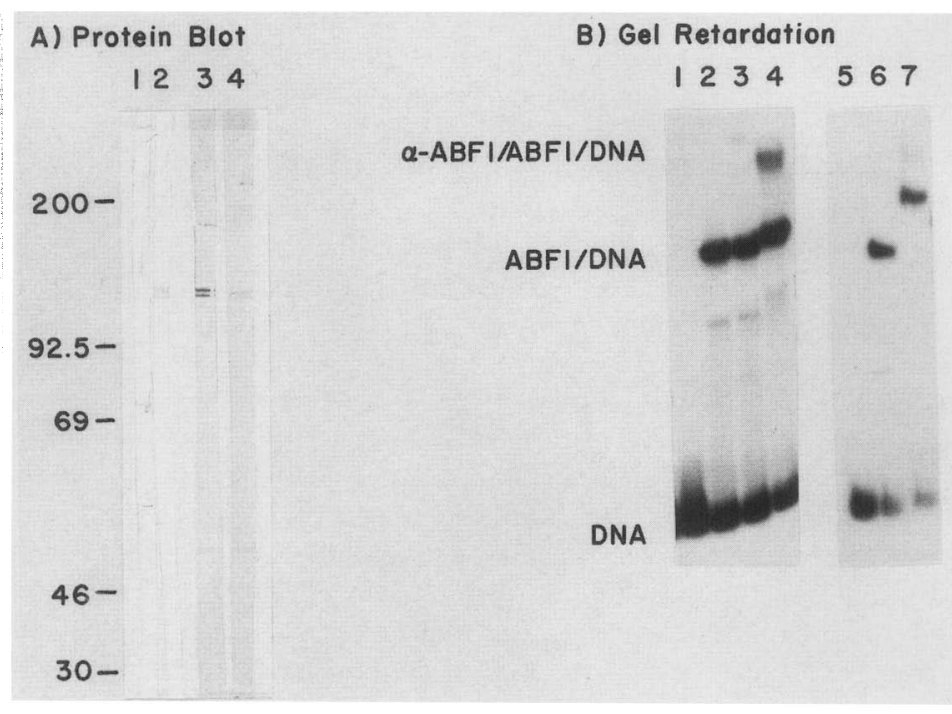

Figure 1. Antibody specificity to ABF I. (A) Immunoblot of partially purified ABF I (dsDNA cellulose fraction). Blots were probed with preimmune rabbit serum (lane 1), antiABF I rabbit serum (lane 2), mAb 6Cl1G4 (lane 3), or mAb 2E7E9 (lane 4). Rabbit sera were used at $1: 100$ dilutions, and the monoclonal hybridoma supernatants were diluted $1: 1$. (B) Gel retardation using an ABF I-domain B fragment. Binding assays contained no protein (lanes 1 and 5), $30 \mathrm{ng}$ of affinity-purified ABF I (lanes 2 and 6), or $30 \mathrm{ng}$ of affinity-purified $A B F$ I with preimmune rabbit serum (lane 3), immune rabbit serum (lane 4), or mAb 6C11G4 (lane 7). All reactions contained $2 \mathrm{ng}$ of a labeled HindIII-BglII fragment from YRp7 and $1 \mu \mathrm{g}$ of salmon sperm DNA as a nonspecific competitor. Positions of molecular weight markers are shown in $A$. Mobilities of free DNA probe and DNA-protein complexes are indicated in $B$.

poly $(A)^{+}$RNA were hybridized to DNA and RNA probes from the cloned DNA of interest. Figure 3 shows that two transcripts, one of $1.1 \mathrm{~kb}$ and another of $2.6 \mathrm{~kb}$, were detected in blots probed with the $\lambda$ gt11-15a insert. Because of the apparent $135-\mathrm{kD}$ molecular mass of ABF I, we suspected that the $2.6-\mathrm{kb}$ transcript encoded this protein. To localize the genes encoding the two transcripts, a series of smaller DNA fragments within the 15a insert (labeled a-g in Fig. 2) were used as hybridization probes. The two transcripts localized to adjacent regions within the cloned DNA (Fig. 3, lanes a-g). The EcoRI fragment encoding both transcripts (Fig. 2) was isolated from $\lambda$ gt 11-15a and subcloned in both orientations adjacent to the T7 RNA polymerase promoter in the vector Bluescript. Strand-specific RNA probes of the $15 \mathrm{a}$ insert were synthesized in vitro and were used to determine the orientations of the $2.6-$ and $1.1-\mathrm{kb}$ yeast genes. Probes complementary to the top strand of the 15a insert (in the orientation shown in Fig. 2) detected the $2.6-\mathrm{kb}$ transcript, whereas those complementary to the bottom strand detected the 1.1-kb transcript (Fig. 3, lanes $T$ and $B$ ). Results of these experiments are summarized above the restriction map in Figure 2. The 2.6-kb mRNA is transcribed from left to right, and all but $\sim 200$ $\mathrm{bp}$ of the $5^{\prime}$ end are within the $15 \mathrm{a}$ insert. The $1.1-\mathrm{kb}$ mRNA is derived from an adjacent gene that is transcribed in the opposite direction.

Our second approach to identifying the $A B F 1$-coding sequence involved characterization of polypeptides produced in bacteria from the cloned yeast DNA inserts. A igtl1-15a-derived EcoRI fragment encoding both the 2.6- and 1.1-kb transcripts was subcloned into the Bluescript polylinker such that the 5 ' end of the $2.6-\mathrm{kb}$ yeast gene was fused downstream of a sequence encoding 37 amino-terminal amino acids of $\beta$-galactosidase. The resulting plasmid was called pBS-15a (Fig. 2). The plasmid was introduced into $E$. coli, and crude cell lysates prepared from cultures induced with isopropyl- $\beta$-D-thiogalactopyranoside (IPTG) and from uninduced cells were analyzed by protein blotting with anti-ABF I polyclonal
Figure 2. Restriction map of yeast ABF I genomic region and structure of cloned inserts. The restriction map (top) was determined from the largest genomic clone. The symbols for the restriction enzymes are $\mathrm{B}$ (BamHI), Bg (BglII), H (HindIII), K (KpnI), P (PstI), R $(E c o R I)$, and $S(S p e I)$. The relative boundaries and direction of the $2.6-\mathrm{kb}$ ABF I and $1.1-\mathrm{kb}$ genes, as defined by Northern analysis, are indicated by the wavy lines. The lettered brackets under the map indicate the DNA fragments used as hybridization probes. The horizontal bars show the positions and sizes of yeast inserts in $\lambda$ t11 and YEp24. Also shown are yeast inserts subcloned into the $1 a c Z$ gene of the Bluescript expression vector. These constructs were used in the expression of fusion proteins in E. coli.

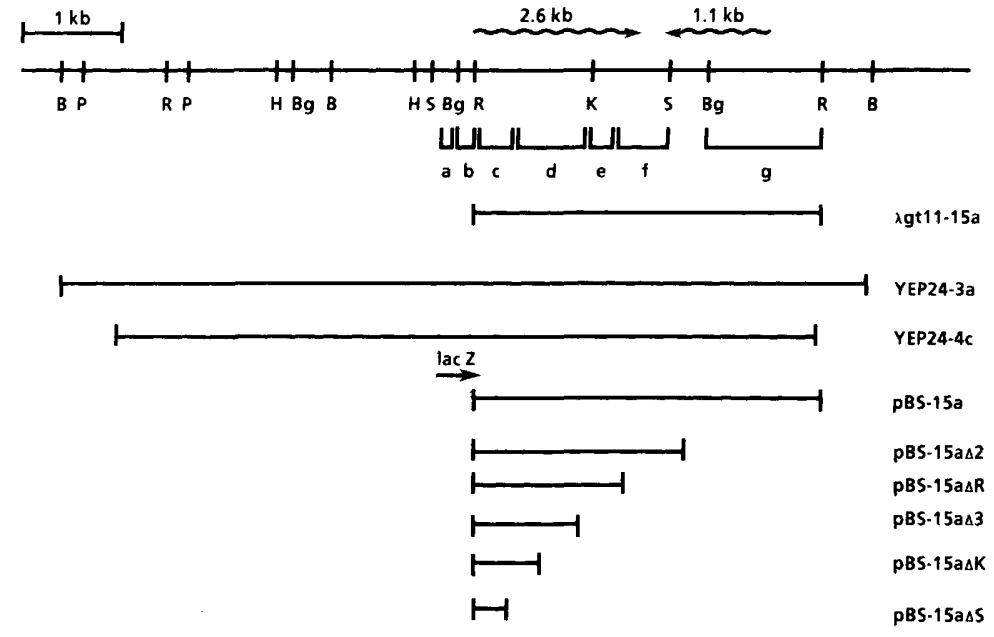




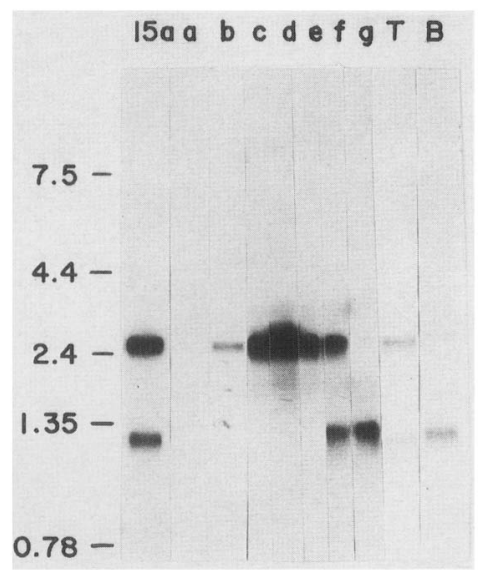

Figure 3. Northern analysis defines two yeast genes. Yeast poly(A) RNA ( $5 \mu \mathrm{g}$ ) was electrophoresed on a formaldehydeagarose gel and transferred to nitrocellulose. The nitrocellulose strips were hybridized to radioactive probes corresponding to the entire $\lambda g t 11-15 a$ insert or subcloned fragments $(a-g)$ of the cloned inserts depicted in Fig. 2. (a) SpeI-BgIII fragment; (b) BgIII-EcoRI fragment; (c) EcoRI-StuI fragment; (d) StuI-KpnI fragment; $(e) K p n I-E c o R V$ fragment; $(f) E c o R V-E c o R V$ fragment; $(g)$ BglII-EcoRI fragment. T7 RNA polymerase was used to generate ribonucleotide probes complementary to the top $(T)$ or bottom (B) strand of the 15a insert, as shown in Fig. 2. RNA markers (BRL) were used as molecular weight standards.

antisera (Fig. 4A). Extracts prepared from cells containing the vector without insert did not contain antiABF I cross-reactive material (lanes 1 and 2). In extracts from cells containing pBS-15a, even in the absence of IPTG, several polypeptides were recognized by the polyclonal antisera, verifying that the $15 \mathrm{a}$ insert expressed ABF I epitopes (lane 3). Expression of these polypeptides was elevated in cells grown in IPTG (lane 4), suggesting that the $15 \mathrm{a}$ insert was expressed from the $1 a c Z$ promoter, consistent with the direction of transcription of the $2.6-\mathrm{kb}$ mRNA deduced by Northern analysis. The largest polypeptide recognized by the antibodies (lanes 3 and 4) had a mobility corresponding approximately to the mobility of purified yeast ABF I.

To map regions within the $15 \mathrm{a}$ insert that expressed ABF I-related antigenic determinants, a series of deletions beginning in the region $3^{\prime}$ to the $2.6-\mathrm{kb}$ gene in pBS-15a were constructed (Fig. 2); and polypeptides expressed from the resulting truncated genes were examined. Deletion of the 1.1-kb yeast gene (clone pBS-15a $\Delta 2$ ) did not affect expression of anti-ABF I cross-reactive polypeptides (Fig. 4A, lanes 5 and 6). However, serial 3' deletions through the rest of the $2.6-\mathrm{kb}$ coding sequence resulted in expression of progressively smaller polypeptides (lanes 7-14). For each deletion, expression of the cross-reactive polypeptides remained IPTG inducible. We presumed and subsequently verified by sequence analysis that these deletions remove protein-coding sequences from the carboxyl terminus of $\mathrm{ABF}$, resulting in the expression of truncated products. Thus, the region of the $15 \mathrm{a}$ insert coding for the ABF I-related poly- peptides is identical to the $2.6-\mathrm{kb}$ yeast gene defined by Northern analysis.

Antigenic determinants specific to the anti-ABF I monoclonal antibodies described above were also examined (Fig. 4B). As observed with the polyclonal antisera, two of the monoclonal antibodies recognized polypeptides in extracts of cells carrying pBS-15a or pBS-15a $\Delta 2$ but did not react with extracts from cells containing the vector alone. Interestingly, the pattern of bands recognized by each monoclonal antibody differed, suggesting that the antibodies react with different epitopes. Protein blot analysis of the truncated polypeptides showed that $\mathrm{mAb} 2 \mathrm{E} 7 \mathrm{E} 9$ recognized polypeptides in each of the extracts (Fig. 4B, lanes 3-7), including the extract from cells expressing only 400 bp of yeast DNA at the $5^{\prime}$ end of the $15 \mathrm{a}$ insert. In contrast, $\mathrm{mAb} 6 \mathrm{C} 11 \mathrm{G} 4$ reacted with polypeptides specific to the pBS-15a $\Delta 2$ insert (lane 10) but failed to recognize the ABF I-related polypeptides in extracts from cells expressing the smaller 15a-derived inserts (lanes 11-14). These data indicate that the individual monoclonal antibodies recognize different determinants on the bacterially produced protein and provide additional evidence that the yeast DNA insert contains authentic ABF I-coding sequences.

\section{Overproduction of $A B F I$ in yeast}

To verify that the cloned yeast DNA inserts contained the $A B F 1$ gene, we transformed yeast with the YEp24-3a and YEp24-4c clones and looked for overproduction of $A B F$ I. Because of their specificity for ABF I, monoclonal antibodies were used as probes to determine the relative quantities of $\mathrm{ABF} I$ in crude yeast extracts. As shown in Figure 5A, extracts from transformants carrying either YEp24-3a (lane 2) or YEp24-4c (lane 3) contained levels of ABF I three- to fourfold higher than extracts from transformants carrying the vector alone (lane 1). Both the 130 - and $135-\mathrm{kD} \mathrm{ABF}$ I polypeptides were overexpressed, consistent with their being products of the same gene. Because of the large amounts of nonspecific DNA-binding proteins present in these crude extracts, it was not possible to correlate increased ARS1-specific binding activity with overproduction at this level of $A B F 1$ expression.

To increase the level of ABF I overproduction, we fused the $A B F$ I open reading frame (ORF) to the yeast GAL1 promoter and introduced the construct into yeast on a centromere-containing plasmid. The GAL1 promoter is strongly activated by growth in media containing galactose. Yeast transformants containing the GAL1/ABF1 fusion or the vector alone were grown on media containing raffinose (uninduced), followed by the addition of galactose. Immunoblot analysis of whole-cell extracts showed little detectable ABF I in strains grown in the absence of galactose induction (Fig. 5A, lane 5) or in the control strain carrying vector alone after galactose induction (data not shown). However, $>20$-fold overproduction of $\mathrm{ABF}$ I was observed in the strain carrying the GAL1/ABF1 fusion, following galactose induction (lane 6). We also quantitated the levels of ARS1-specific 


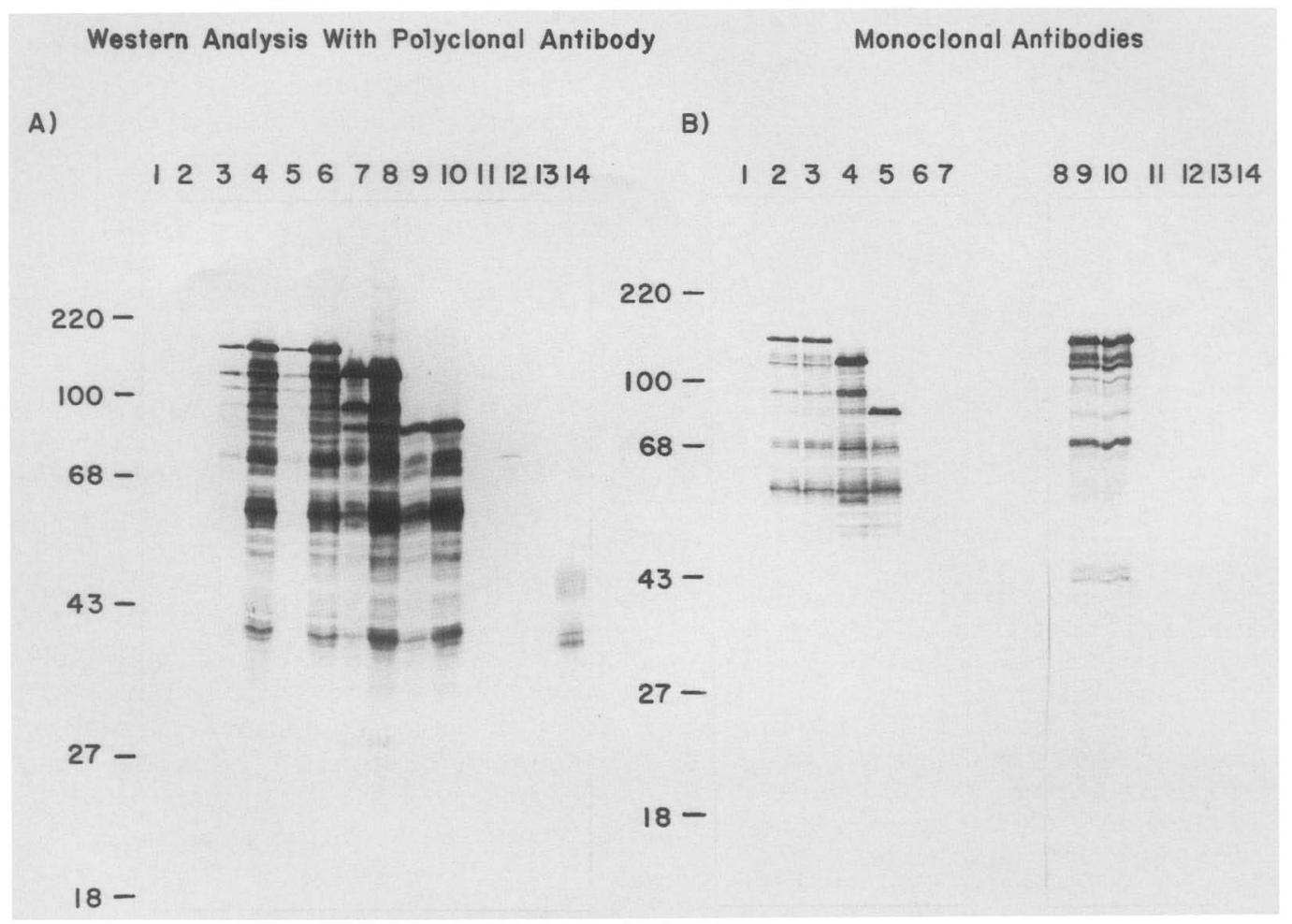

Figure 4. Antibodies recognize bacterially produced $\beta$-gal/ABF I fusion proteins. Yeast DNA inserts (shown in Fig. 2) were subcloned into the lacZ gene of the expression vector Bluescript. Bacterial extracts were prepared from uninduced and IPTG-induced cultures, electrophoresed on a $10 \%$ SDS-polyacrylamide gel, and transferred to nitrocellulose. $(A)$ Immunoblot probed with anti-ABF I polyclonal antisera. Extracts were prepared from cultures carrying Bluescript (lanes 1 and 2), pBS-15a (lanes 3 and 4), pBS-15 $\Delta 2$ (lanes 5 and 6), pBS-15a $\Delta$ R (lanes 7 and 8), pBS-15a $\Delta \mathrm{K}$ (lanes 9 and 10), pBS-15a $\Delta 3$ (lanes 11 and 12), and pBS-15a $\Delta$ S (lanes 13 and 14). Extracts shown in lanes $1,3,5,7,9,11$, and 13 were from cultures grown in the absence of IPTG, extracts shown in lanes 2, 4, 8, 10, 12, and 14 were from cultures grown in the presence of $10 \mathrm{mM}$ IPTG. $(B)$ Immunoblots probed with monoclonal antibodies. Extracts were prepared from IPTG-induced cultures carrying Bluescript (lanes 1 and 8), pBS-15a (lanes 2 and 9), pBS-15a $\Delta 2$ (lanes 3 and 10), pBS-15a $\Delta$ R (lanes 4 and 11), pBS-15a $\Delta \mathrm{K}$ (lanes 5 and 12), pBS-15a $\Delta 3$ (lanes 6 and 13), or pBS-15a $\Delta S$ (lanes 7 and 14). mAb 2E7E9 (lanes 1-7) and mAb 6C11G4 (lanes 8-12) were used as probes. A weak reaction between 2E7E9 and extracts from pBS-15a $\Delta S$ was visible in the original blot. The positions of protein standards are shown.

binding proteins in these extracts by gel retardation, as shown in Figure 5B. When the crude extracts were incubated with an ARS1 - domain B fragment (lanes 2-5), we observed a single DNA-protein complex that comigrated with the complex formed with purified ABF I (lane 10). This binding activity was 20 -fold greater in extracts from galactose-induced cultures of strains carrying the GAL1/ABF1 fusion (lanes 4 and 5) than in control extracts (lanes 2 and 3), consistent with the protein data. Competition with an oligonucleotide specific to the $\mathrm{ABF}$ I-binding site verified that this DNA-binding activity was ABF I (lanes 6-9). The results provide proof that the cloned DNA contains the $A B F 1$ gene.

\section{Analysis of the $\mathrm{ABF} 1$ sequence}

We determined the nucleotide sequence of $3 \mathrm{~kb}$, starting from the left-most SpeI site shown in Figure 2. The sequence spans the region coding for the 2.6-kb $A B F 1$ gene defined above and part of the 1.1-kb gene (Fig. 6). Sequence numbering begins at the Spel site. The sequence contains a single, large ORF (nucleotides 190-2488) with a $5^{\prime}$ end that coincides with the $5^{\prime}$ limit of the $A B F 1$ gene defined by Northern analysis. Direct expression of the BglII-SpeI fragment in $E$. coli by fusion to an $E$. coli promoter results in production of an ABF I-related protein that comigrates with the $130-\mathrm{kD}$ polypeptide of yeast ABF I (data not shown), indicating that this sequence is sufficient to code for ABF I. The first ATG codon at nucleotide 295 is preceded by an $\mathrm{A}$ at the -3 position that is conserved and a $G$ at +4 that is partially conserved in translation start sites (Kozak 1983). Therefore, we propose that this ATG serves as the initiator for $A B F$ I. No conserved splice site sequences were found in the DNA sequence. The termination codon TAG /nucleotide 2489/ is immediately upstream of a region of A/T-rich DNA, possibly involved in mRNA termination. Consistent with the position of the $1.1-\mathrm{kb}$ gene, another ORF of the opposite orientation was observed $3^{\prime}$ of the $A B F 1$ gene. This ORF has a termination codon at nucleotide 2666 and extends beyond the end of the sequenced DNA. 
A) 1234
B) 56
1234567891011

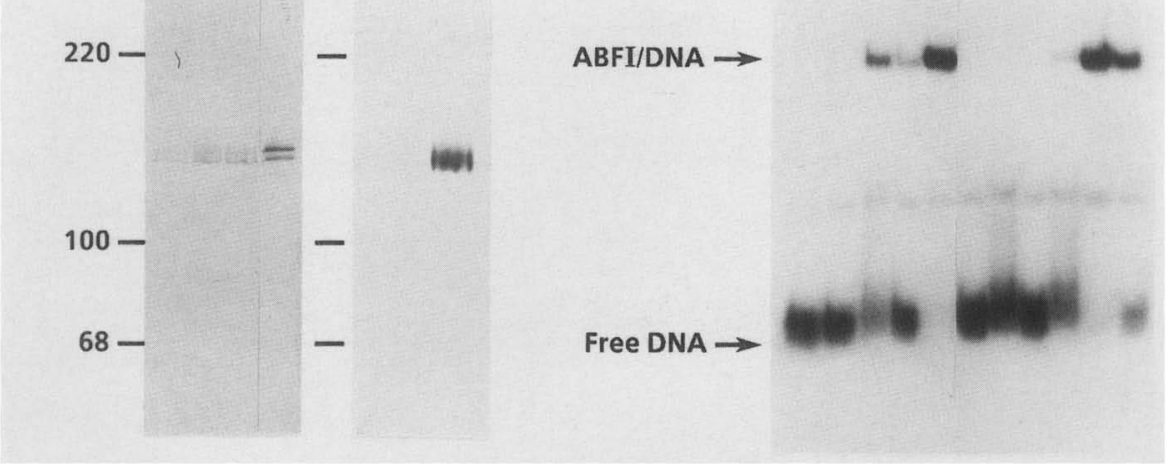

Figure 5. Overproduction of $A B F I$ and its binding activity in yeast. $(A)$ Immunoblot of crude yeast extracts. (Lane 1) Fifty micrograms of extract from the control SEY6210.5 strain transformed with YEp24; (lanes 2 and 3) $50 \mu \mathrm{g}$ of extract from SEY6210.5 transformed with YEp24-3a and YEp24-4c, respectively; (lane 4) partially purified ABF I $(3 \mu \mathrm{g})$ serves as a marker. The YM603 strain was transformed with a plasmid containing the $G A L 1 / A B F 1$ gene fusion (p68g-3a) and grown in raffinose media (uninduced) or galactose media (induced). (Lane 5) Twenty micrograms of extracts from uninduced cultures; (lane 6) $20 \mu \mathrm{g}$ of extracts from galactose-induced cultures. The mobility of molecular weight standards is indicated. $(B)$ Gel retardation assay. Binding assays were carried out using $2 \mathrm{ng}$ of a labeled HindIII-BgIII fragment from YRp7 and a total of $5 \mu \mathrm{g}$ of unlabeled DNA (salmon sperm DNA with or without the specific oligonucleotide). Reactions contained no protein (lane 1), $2 \mu \mathrm{g}$ (lanes 2 and 6) or $25 \mu \mathrm{g}$ (lanes 3 and 7) of extract from an uninduced YM603/p68g-3a strain, $2 \mu \mathrm{g}$ (lanes 4 and 8 ) or $25 \mu \mathrm{g}$ (lanes 5 and 9) of extract from a galactose-induced YM603/p68g-3a strain, or 30 ng of purified ABF I (lanes 10 and 11). To verify that the binding activity observed corresponds to ABF I, we included $300 \mathrm{ng}$ of element $\mathrm{B}$ oligonucleotide in the reactions analyzed in lanes $6-9$ and 11.

The $A B F 1$ gene codes for a 731 -amino-acid protein with a predicted molecular weight of 81,662 . This is considerably less than the molecular weight of 135,000 estimated by SDS-polyacrylamide gel electrophoresis. We also observed discrepancies between the predicted and observed molecular weights of the E. coli-produced $\beta$-gal/ABF I fusion proteins. For example, sequence analysis predicted that $\mathrm{pBS}-15 \mathrm{a} \Delta \mathrm{R}$ and $\mathrm{pBS}-15 \mathrm{a} \Delta \mathrm{K}$ constructs could encode truncated $\beta$-gal/ABF I fusion products with molecular masses of 87 and $69 \mathrm{kD}$, respectively. The molecular masses observed in Figure 4A were 120 and 87 $\mathrm{kD}$, respectively. Therefore, it seems unlikely that the discrepancy seen with ABF I is attributable to either post-translational modification occurring in yeast or to the conformation of the intact protein. Similar anamolous migration on SDS gels has been reported for a number of other yeast DNA-binding proteins (Hope and Struhl 1985; Shore and Nasmyth 1987; Wiederrecht et al. 1988; Moye-Rowley et al. 1989).

In comparing the sequence with available protein and DNA data bases, we found no strong homologies. Inspection of the ABF I amino acid sequence did reveal a zinc finger motif, $\mathrm{H}-\mathrm{X}_{3}-\mathrm{H}-\mathrm{X}_{4}-\mathrm{C}-\mathrm{X}_{4}-\mathrm{C}$ (residues 57-71), that matches the $\mathrm{H}-\mathrm{X}_{2-4}-\mathrm{H}-\mathrm{X}_{2-15}-\mathrm{C}-\mathrm{X}_{2-4}-\mathrm{C}$ consensus (Berg 1986; Klug and Rhodes 1987). This zinc finger motif is similar in size to the CCHC box found in retroviral gag-encoded nucleic acid-binding proteins. The role that this region plays in DNA binding remains to be determined. The protein contains no obvious regions similar to the helix-turn-helix motifs or leucine zippers characteristic of some DNA-binding proteins (Pabo and Sauer 1984; Landschulz et al. 1988).
The codon usage (59 of 61 possible codons used) shows none of the bias observed in highly expressed yeast genes (Bennetzen and Hall 1981), consistent with the finding that the $A B F 1$ gene is expressed at low levels. Because of a high proportion of aspartic acid residues $(11.4 \%), \mathrm{ABF} I$ is very acidic with a net charge of -60 at neutral $\mathrm{pH}$ and a calculated $\mathrm{pI}$ of 4.74 . The distribution of charge is not random. The amino-terminal region (residues $1-75$ ) is basic (net charge +5 ), as is a small region in the middle of the protein (residues 412-435, charge +10 ). The acidic amino acids predominate at the carboxyl terminus (residues 552-731, charge - 35) and between residues 116 and 268 (charge -28 ). ABF I is also rich in asparagine $(14.8 \%)$ and serine $(9.8 \%)$. Four regions of the protein contain small clusters of asparagine residues.

\section{The $\mathrm{ABF} 1$ gene is essential for viability}

To determine whether the $A B F 1$ and $1.1-\mathrm{kb}$ genes are essential for yeast growth, we disrupted the chromosomal copies of each of these genes. First, a series of insertion mutations in the $15 \mathrm{a}$ fragment were generated in E. coli using the Tn3-LEU2 shuttle mutagenesis system developed by Seifert et al. (1986a,b). Figure 7A shows the insertion sites of the yeast $L E U 2$ gene for five of the mutants isolated. Two of the mutants contain insertions disrupting the $A B F 1$ gene; the remainder contain insertions in the $1.1-\mathrm{kb}$ gene. Second, insertion mutations in the ABF1 gene were introduced into the genome of a homozygous leu2 diploid strain. Southern analysis of DNA isolated from $\mathrm{Leu}^{+}$transformants indicated that one copy of the chromosomal $A B F 1$ gene contained the 
Figure 6. Sequence of the $A B F 1$ gene. The DNA sequence begins at the left-most SpeI site of YEp24-3a insert and extends through the region encoding the $2.6-\mathrm{kb}$ transcript. The predicted amino acid sequence of ABF I is shown in the one-letter code. Cysteine and histidine residues defining the zinc finger motif are circled. The sequences of both strands were determined either from a series of nested deletions in Bluescript or from insert-specific primers by the Sanger dideoxy chain-termination method. Every base was represented at least twice. For preparing deletions, pBS-15a was cleaved with PstI and StuI. PstI cleaved in the polylinker and StuI site is 400 bp downstream of the EcoRI site at the $5^{\prime}$ end of the gene (Fig. 2). Exoll deletions were carried out from the StuI site. For sequencing the opposite strand, pBS-15a' (with the EcoRI fragment in the opposite orientation) was cleaved with PstI and BglII. The BglII site is within the 1.1-kb RNAcoding region (see Fig. 2). The digested DNAs were ligated and transformed into $E$. coli. A series of overlapping deletions was chosen from among resulting transformants for DNA sequencing. To complete the $5^{\prime}$ end of the gene, the SpeI-EcoRI fragment was cloned in Bluescript and sequenced. The inserts in pBS-15a $\Delta R$, pBS- $15 a \Delta \mathrm{K}$, and pBS-15a $\mathrm{AS}$ (Fig. 2) were sequenced from the restriction site toward the $3^{\prime}$ end of the gene on one strand only.

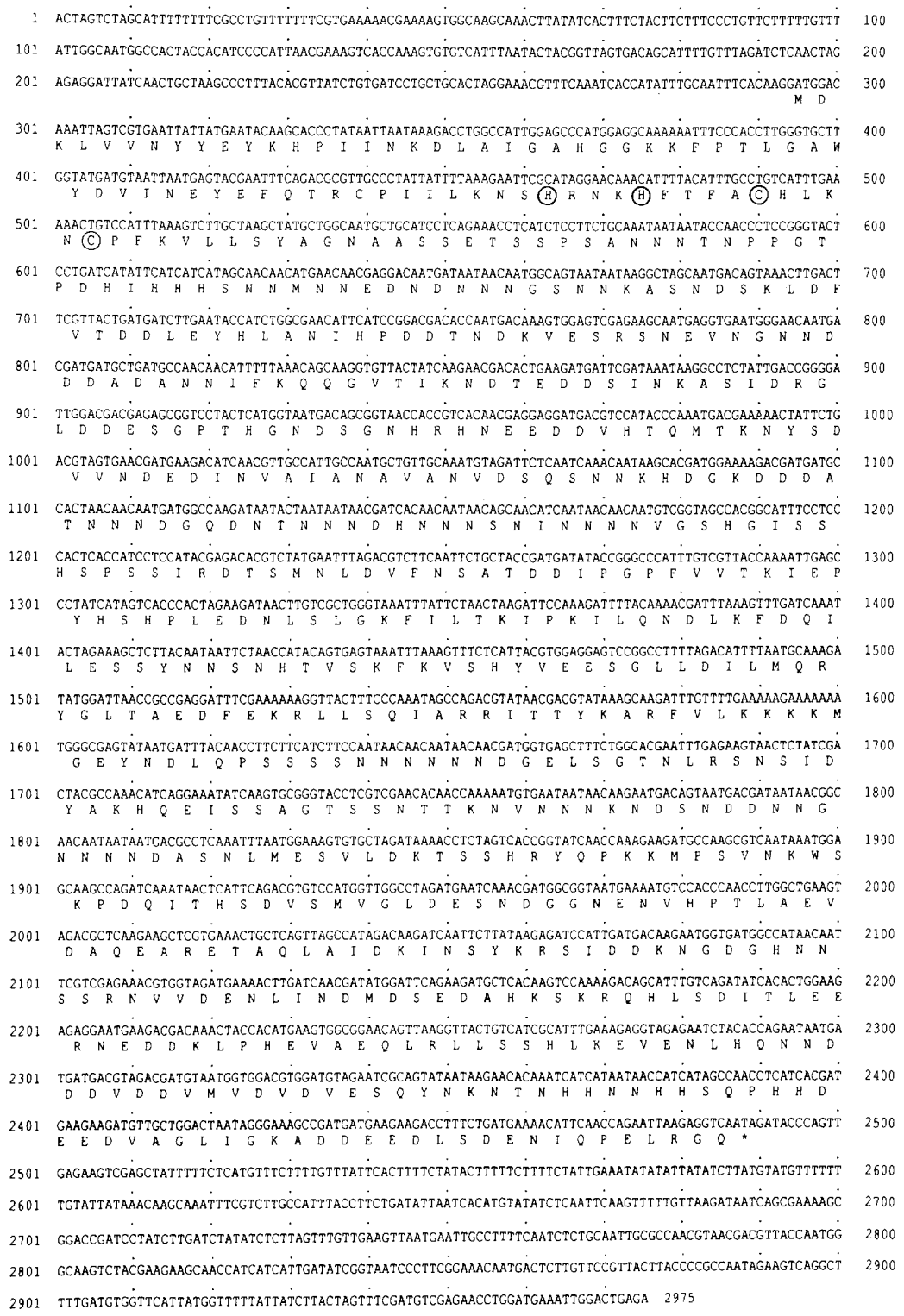
200 400 500 600 700 800 900
LEU2 insertion. Figure 7B shows a Southern blot of $B$ III-digested DNA hybridized to the $15 \mathrm{a}$ insert. Two $B g l I I$ fragments $\{3.3$ and $4.1 \mathrm{~kb}\}$ were detected in the undisrupted diploid strain, consistent with the restriction analysis of the cloned inserts. Strains transformed with either of the two $A B F I:: L E U 2$ disruptions contained one intact chromosomal copy of the $A B F 1$ gene and one copy containing a 7.6-kb $B g l I I$ fragment indicative of the $3.5-\mathrm{kb}$ Tn3-LEU2 insertion (lanes 2 and 3). These strains were sporulated and subjected to tetrad analysis. Almost all of the tetrads ( 23 of 25 for the abf1:: LEU2-1 disruption and 21 of 22 for the $a b f 1::$ LEU2-3 disruption) gave only two viable spores; the remainder gave only one viable spore. The nonviable spores failed to grow beyond the two- to four-cell stage. The two viable spores were $\mathrm{Leu}^{-}$. These results indicate that $A B F 1$ is an essential, single-copy gene.

To test further the role of ABF I in yeast growth, we constructed strains from which we could remove the functional copy of the $A B F 1$ gene during vegetative growth. A ura3/ura3 diploid strain heterozygous for the abf1:: LEU2 disruption was transformed to $\mathrm{Ura}^{+}$with a plasmid carrying the $U R A 3$ and $A B F 1$ genes (YEp24-4c). Following sporulation, four viable spores $/$ two $\mathrm{Leu}^{+}$and two $\mathrm{Leu}^{-}$) were observed in each tetrad dissected, indicating that the plasmid-borne $\mathrm{ABF} 1$ gene could complement the $a b f 1::$ LEU2 disruption. When these strains were replica-plated on medium containing 5-fluoro-orotic acid (5-FOA) to select against the URA3-bearing plasmid, growth was observed only in Leu- strains, which presumably carry an intact $A B F 1$ gene. No viable $\mathrm{Leu}^{+}$cells were observed on 5-FOA plates, indicating that the strains carrying the $a b f 1:: L E U 2$ disruption could not form colonies in the absence of the plasmid carrying $A B F 1$. These results confirm that the $A B F 1$ gene is essential for vegetative growth, and they suggest 
A)

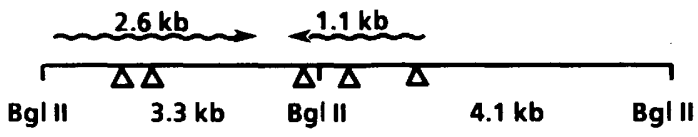

Tn3 Insert
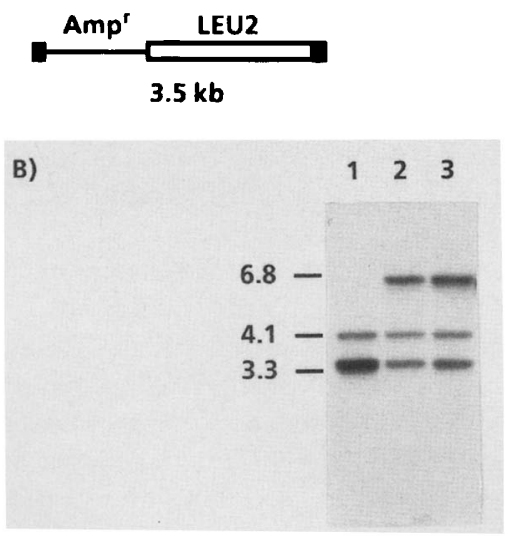

Figure 7. Gene disruption of $A B F 1$. Random insertions of the LEU2 gene into the 15a fragment were generated using the transposon system developed by Seifert et al. (1986a,b). The mutant fragments were introduced into the diploid strain SEY6210.5 by homologous recombination, replacing the wildtype copy of one of the homologs. (A) Map of insertion sites within the $2.6-\mathrm{kb} A B F 1$ gene and the adjacent $1.1-\mathrm{kb}$ gene. $(\Delta)$ The sites of five independent Tn3-LEU2 insertions. The two left-most insertions correspond to the $a b f 1:: L E U 2-1$ and $a b f 1::$ LEU2-3 mutants. $(B)$ Southern analysis of DNA isolated from the nondisrupted diploid (lane 1) and from abf1 :: LEU2-1 (lane 2) and abf1:: LEU2-3 (lane 3) diploid transformants. Twenty micrograms of DNA from the indicated strains was digested with BglII. This enzyme does not cut within the Tn3LEU2 insert. The blot was probed with ${ }^{32}$ P-labeled $15 \mathrm{a}$ insert.

that there is insufficient ABF I in the cell after plasmid loss to support the number of cell divisions necessary to give rise to a visible colony.

We also tested the effect of disruption of the 1.1-kb gene adjacent to $A B F 1$. We found that it was possible to introduce copies of the 1.1-kb gene carrying Tn3-LEU2 insertions into the genome of a leu2 haploid strain. Southern analysis verified that the chromosomal copy of this gene had the expected disrupted structure /data not shown). Growth of this strain was not affected by this gene disruption, indicating that the 1.1-kb gene is not essential.

\section{Chromosomal mapping of ABF1}

Pulsed-field electrophoresis was used to determine the chromosomal location of the $A B F 1$ gene (Lai et al. 1989). $A B F 1$ hybridized only to chromosome $\mathrm{V}$ (Fig. 8).

\section{Discussion}

Recently, we described the purification of ABF I, a
DNA-binding protein that binds to functionally important regions at several yeast ARSs (Sweder et al. 1988). In the current work, we used antisera directed against ABF I to screen a yeast genomic $\lambda g t 11$ library to isolate the gene encoding this protein. The identity of the cloned gene was confirmed by two methods. First, two monoclonal antibodies specific to ABF I were found to react to clone-derived polypeptides produced in E. coli. Further experiments showed that the antigenic determinants for these antibodies map to opposite ends of the protein. Second, controlled expression of the cloned gene in yeast resulted in overproduction of the ABF I protein and DNA-binding activity.

\section{$A B F$ I contains a zinc finger motif}

The $A B F 1$ gene codes for a 731 -amino-acid protein that shows no strong homologies to sequences present in available protein or DNA data bases. ABF I does contain a region that matches the zinc finger DNA-binding motif, however. These metal-binding, nucleic acidbinding domains were first described for the Xenopus transcription factor TFIIIA (Brown et al. 1985; Miller et al. 1985) and were subsequently found in a number of transcriptional activators and DNA-binding proteins (for review, see Berg 1986; Klug and Rhodes 1987; Evans and Hollenberg 1988). Zinc fingers have been analyzed by a wide variety of methods leading to the proposal that two pairs of Cys and/or His residues in each finger coordinate a zinc(II) ion, and the resulting metalloprotein structure interacts with the DNA. Two major classes of zinc fingers have been well characterized. The $\mathrm{Cys}_{2} / \mathrm{His}_{2}$ finger (consensus, C- $\mathrm{X}_{2,4}-\mathrm{C}-\mathrm{X}_{3}-\mathrm{F}-\mathrm{X}_{5}-\mathrm{L}-\mathrm{X}_{2}-\mathrm{H}-\mathrm{X}_{2}-\mathrm{H}$ ) is found in TFIIIA, the yeast transcription factors ADR1 and SWI5, the human transcription factor SP1, and proteins encoded by various Drosophila developmental genes. The $\mathrm{Cys}_{2} / \mathrm{Cys}_{2}$ finger $\left(\mathrm{C}-\mathrm{X}_{2}-\mathrm{C}-\mathrm{X}_{13}-\mathrm{C}-\mathrm{X}_{2}-\mathrm{C}\right)$ is found in the steroid receptor superfamily and the yeast transcription factors GAL4, PPR1, ARGR11, and LAC9. As compared to other yeast DNA-binding proteins, $\mathrm{ABF}$ $I$ is novel in that its zinc finger motif belongs to a third class found in the single-stranded nucleic acid-binding proteins, encoded by retroviral gag genes and the T4 phage gene 32 (Berg 1986; Giedroc et al. 1986). This class of 'stubbier' fingers contains only four to five residues in the loop between the Cys and/or His pairs. Studies have shown that this motif is capable of binding zinc /Green and Berg 1989); however, site-specific DNA binding remains to be demonstrated. Further studies to localize the ABF I DNA-binding domain should determine whether this motif plays a role in DNA binding.

In examining the ABF I amino acid sequence, we found several features that are shared with other yeast DNA-binding proteins. First, ABF I contains several regions that are high in acidic residues. These regions may be functionally analogous to the acidic activation sequences found in transcription factors such as GAL4 and GCN4 (Hope and Struhl 1986; Ma and Ptashne 1987). Current models of transcriptional activation propose an interaction between these regions and the transcription 


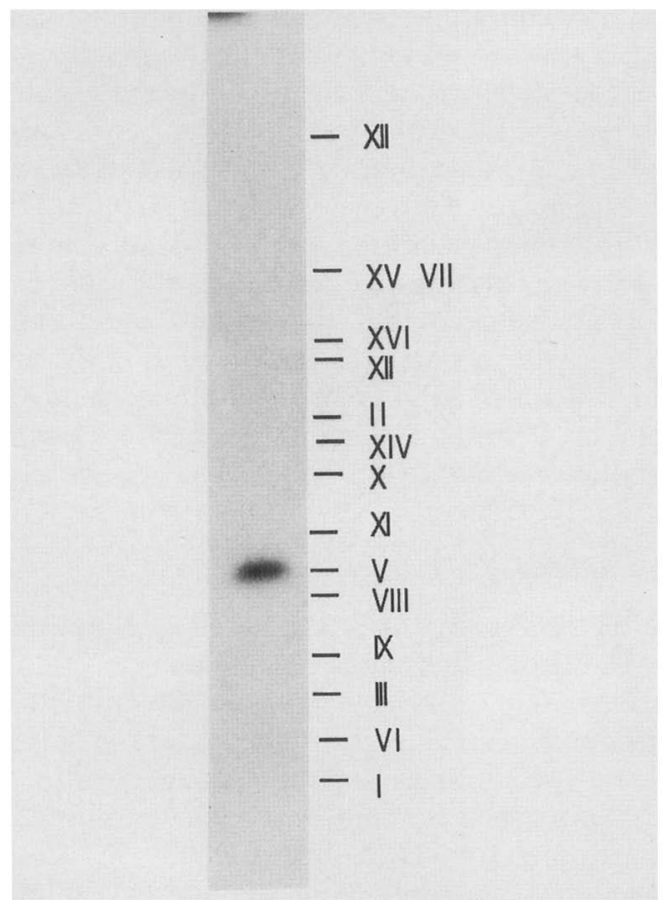

Figure 8. Yeast chromosomal blot. Chromosomes $\{10 \mu \mathrm{g}$ chromosomal DNA) from the strain YNN 295 were separated by pulsed-field electrophoresis (Lai et al. 1989), transferred to nitrocellulose membrane, and hybridized to ${ }^{32} \mathrm{P}-$ labeled $\lambda$ gt 1 1-15a insert (Fig. 2). The distances migrated by the ethidium bromide-stained chromosomes are indicated.

machinery (Mitchell and Tiian 1989). Second, ABF I is rich in asparagine residues. Similar amino acid compositions have been reported for RAP I and HSTF (Shore and Nasmyth 1987; Wiederrecht et al. 1988). The asparagine residues are unevenly distributed such that four small asparagine clusters are apparent in ABF I. Secondary structure analysis based on the Chou-Fasman algorithm (Chou and Fasman 1977) predicts strong turn potential at these clusters, suggesting that these regions have unusual conformational characteristics. No functional role for these regions has been defined.

\section{Roles of $A B F$ I in transcription and replication}

Recent indications suggest that $\mathrm{ABF}$ I binds to a variety of genetic elements that serve diverse functions in regulating DNA replication and gene expression. The fact that $\mathrm{ABF}$ I was determined to be essential for growth supports this possibility. Deletion analyses have shown that the regions containing the ABF I-binding site stimulate (but are not essential for) the activity of ARS1 and the ARS at HMR E (Abraham et al. 1984; Celniker et al. 1984; Brand et al. 1985, 1987; Srienc et al. 1985; Snyder et al. 1987; Diffley and Stillman 1988; Strich et al. 1986). In addition, the $\mathrm{ABF}$ I-binding site at $H M R E$ (B element) has been shown to be important in silencer activity and to possess a segregation function (Brand et al. 1985, 1987; Kimmerly and Rine 1987; Kimmerly et al. 1988).
In the proper context, the B element can also function as an upstream activation sequence (UAS) element (Brand et al. 1987). Thus, these studies demonstrated that ABF I can act in transcriptional activation and repression, as well as stimulating replication.

Since the initial characterization of $\mathrm{ABF}$ I, a number of independently identified proteins $/ O B F 1, G F 1$, SUF, $\mathrm{TAF}$, and $\mathrm{Y}$ protein) have been found to bind to DNA sites conforming to the ABF I consensus (RTCRYN $\left.{ }_{5} A C G\right)$. OBF1 was shown to bind telomeric ARSs (ARS120, ARS131C, and ARS131S) and the singlecopy ARS121 (Eisenberg et al. 1988; Francesconi and Eisenberg 1989). Linker substitution mutagenesis at ARS121 demonstrated that the OBF1-binding site was required for optimal ARS activity (Walker et al. 1989). Other factors were identified on the basis of their binding to various promoter elements. GF1 binds to the 5 -flanking sequences in a number of nuclear genes encoding imported mitochondrial proteins (Dorsman et al. 1988); SUF and TAF bind to promoters of genes encoding ribosomal proteins S33 and L3 (TMC1 gene), respectively (Vignais et al. 1987; Hamil et al. 1988); and Y protein binds to the promoter of the phosphoglycerate kinase gene (Stanway et al. 1987). In several cases, these binding sites were located in regions that regulated transcription. For example, Hamil et al. (1988) showed that the TAF-binding site could act as a UAS element in the TCM1 promoter or in a heterologous promoter that lacked a functional UAS. Point mutations at this site that reduced TAF binding also decreased UAS activity in vivo.

Several lines of evidence suggest that these factors are the same protein. The mobilities in SDS gels suggest that ABF I, OBF1, and TAF are in the same 125- to 150$\mathrm{kD}$ range (Diffley and Stillman 1988; Hamil et al. 1988; Sweder et al. 1988; Francesconi and Eisenberg 1989). Competitive binding and DNase I footprinting analyses established that ABF I (SBF-B), OBF1, and GF1 bind to identical sites at ARS1 and HMR E (Diffley and Stillman 1988; Dorsman et al. 1988; Sweder et al. 1988; Francesconi and Eisenberg 1989). Recently, partially purified GF1 was also shown to specifically bind SUF- and TAFbinding sites (Dorsman et al. 1989). Furthermore, linker substitution or point mutations in the binding sites cause a concomitant loss of ABF I, OBF1, GF1, or TAF binding and biological activity only when the mutations fall within the ABF I consensus (Hamil et al. 1988; Kimmerly et al. 1988; Dorsman et al. 1989; Walker et al. 1989). These data are consistent with a role of ABF I in regulating transcription and/or replication at these sites. However, it cannot be ruled out that other proteins with $\mathrm{ABF}$ I-like binding properties mediate some of these functions. Direct proof of $A B F$ I function will require characterization of conditional $a b f 1$ mutants. Isolation of these mutants is currently in progress.

It is noteworthy that the binding sites described above are found in constitutively expressed genes that are regulated by the carbon source used for growth. A computer search to identify other ABF I-binding sites in the yeast genome revealed 58 matches present in the $5^{\prime}$-flanking 
regions of genes transcribed by RNA polymerase II. These included genes encoding proteins involved in transcription (subunits of RNA polymerase I and III), translation (ribosomal proteins, aa-tRNA synthetases), glycolysis (PGK,ENO2, TDH3), respiration (mitochondrial proteins), cell structure ( $\beta$-tubulin), and cell-cycle progression (CDC25, $C D C 16$, calmodulin). In many respects, ABF I-binding sites are similar to those found for the silencer DNA-binding protein, RAP I (repressor-activator protein) (also called GRFI and TUF) (Huet and Sentenac 1987; Shore and Nasmyth 1987; Shore et al. 1987; Buchman et al. 1988a,b; Kimmerly et al. 1988). This protein acts as a transcriptional activator and repressor, coordinating expression of as many as 45 genes that code for proteins involved in cell growth (Buchman et al. 1988b; Capieaux et al. 1989|. Both ABF I-and RAP I-binding sites are found in the same promoters of several genes. On the basis of these observations, it is tempting to speculate that ABF I and RAP I coordinately regulate transcription of growth-related genes and initiation of replication in response to growth conditions. The dual role of a protein in transcriptional control and replication is not unique. In mammalian cells, several proteins have been shown to regulate transcription, as well as stimulate viral replication (Nagata et al. 1982; Rawlins et al. 1984; Jones et al. 1987; Santoro et al. 1988).

\section{Possible mechanisms of $A B F$ I action}

Several models could explain the diverse roles of ABF I in regulating transcription and replication. First, ABF I may exist in several functionally distinct states. In crude yeast extracts, ABF I is present in two forms, both capable of specifically binding DNA. We have shown that both are products of the same gene. Bacterially produced $\mathrm{ABF}$ I comigrates with the $130-\mathrm{kD}$ form (data not shown), suggesting that protein modification in yeast results in the $135-\mathrm{kD}$ species. The nature of this change is not known, though modifications, such as phosphorylation, have been observed to affect the mobility of other DNA-binding proteins (Hoeffler et al. 1988; Sorger and Pelham 1988). The different forms of ABF I may mediate different functions or represent different functional states of the protein. Recent results suggest that growth in different carbon sources affects the relative abundance of the two forms of ABF I (K. Oegema, unpubl.). This change may be analogous to the phosphorylation and activation of the heat shock transcription factor observed after heat shock (Sorger et al. 1987; Sorger and Pelham 1988). Second, specific protein-protein interactions with other DNA-binding factors (and possibly other proteins/ may dictate ABF I function. The context of the ABF I-binding site is clearly important. For example, in combination with a RAP I-binding site at $H M R E$, the ABF I-binding site is involved in repressing transcription. However, either binding site alone acts as a UAS in a heterologous promoter. Similar observations have been made for the DNA-binding protein, MCM1 (also called PRTF/GRM) (Jarvis et al. 1989; Passmore et al. 1989|. The MCM1-binding site can function as a ge- neric UAS, as a cell-type-specific UAS in conjunction with an $\alpha 1$-binding site, as a cell-type-specific repressor element with an $\alpha 2$-binding site (Bender and Sprague 1987; Jarvis et al. 1988; Keleher et al. 1988). Interaction between DNA-binding proteins could prevent or enhance direct interactions with transcription (or replication) machinery or alter the local chromatin structure, making transcription more or less likely.

ABF I may play a role in the higher order structure of the genome. Because $\mathrm{ABF}$ I-binding sites have been found in regions with no apparent ARS or transcriptional regulatory elements (Buchman et al. 1988a), it has been proposed that these sites serve as boundaries between adjacent regions of the genome. The fact that the ABF I-binding site plays a role in the segregation of $H M R$ $E$-ARS plasmids also suggests that ABF I is associated with a structural component of the nucleus (i.e., the nuclear scaffold). However, any such association must be weak, as Grasser and co-workers recently found that DNA fragments containing ABF I-binding sites did not bind to isolated nuclear scaffold nor was ABF I-binding activity detected in scaffold protein preparations (Amati and Gasser 1988; Hofmann et al. 1989).

In regulating ARS activity, ABF I-binding sites may be functionally analogous to transcriptional enhancers found adjacent to eukaryotic viral origins. It has been proposed that these regions may stimulate transcription, activating the origin (DePamphilis 1988). Alternatively, factors binding to these enhancers may (directly or indirectly) facilitate interactions between the origin and proteins involved in initiation of replication. Because yeast initiator proteins have not been characterized, it will be interesting to examine proteins that interact with $\mathrm{ABF} I$.

\section{Materials and methods}

Strains and media

Bacterial strains TG-1 (Amersham) and DH5 $\alpha \mathrm{F}^{\prime}$ (BRL) were used in cloning, overproduction of ABF I fusion protein, and isolation of plasmids used in sequencing. The $\lambda g t 11$ genomic library was grown in Y1090 (Young and Davis 1983). E. coli strains RDP146 and NS2114Sm were used in the Tn3 insertion mutagenesis (Seifert et al. 1986a).

ABF I was purified from a protease-deficient strain PEP4D $[M A T \mathbf{a} / \alpha$ his1 + trp1 / + prc1-126/prc1-126 pep4-3 / pep4-3 prb 1-1122/prb1-1122 can1/can1 (Jones 1977)]. All other experiments were carried out in the yeast strain SEY6210.5 [MATa/ a leu2-3, 112/leu2-3, 112 ura3-52/ura3-52 his3- $\Delta 200 /$ his3- $\Delta 200$ trp1-901/trp1-901 lys2-801/ + ade2-101/ + suc2-9/ + mel-/mel[S. Emr, unpubl.)] or haploid derivatives of it, except the galactose induction of the $G A L 1 / A B F 1$ fusion, which was carried out in YM603 [a ura3-52 lys2-8D1 met his3 ade2-101 reg1-501 [Celniker et al. 1984)].

Bacterial media were made as described by Miller (1972). Yeast cells were grown on media (YPD, yeast extract, peptone, dextrose; SD, synthetic minimal) described by Sherman et al. (1979). Diploid strains were sporulated on a solid sporulation media. Counter-selection against plasmids containing the $U R A 3$ gene was performed in media containing $1 \mathrm{mg} / \mathrm{ml} \mathrm{5-FOA}$ (Boeke et al. 1984). For galactose induction of $G A L / A B F 1$ gene fusions, YM603/p68g-3a (see below) strains were grown in YP media containing $2 \%$ raffinose to $A_{595}=0.8$. Glucose-free ga- 
lactose was added to a final concentration of $2 \%$, and cells were harvested $4 \mathrm{hr}$ later.

\section{DNA manipulations}

$\lambda$ DNA was purified using Lambda Sorb (Promega Biotec). DNA fragments were cloned into pBluescript SK (-) (Stratagene) by standard techniques (Maniatis et al. 1982). Insertion of the EcoRI yeast DNA fragment from $\lambda$ gt $11-15 a$ into the EcoRI site of the Bluescript polylinker resulted in fusion of the ABF I ORF with the first 37 codons of $l a c Z$. This plasmid is referred to as pBS-15a (the insert cloned in the opposite orientation is referred to as pBS-15 $\left.a^{\prime}\right)$. Nestled deletions used in DNA sequencing were constructed from pBS-15a and pBS-15a' by the method of Henikoff et al. (1984). The GAL1/ABF1 fusion was made by inserting the 3.2-kb BgIII fragment of YEp24-3a into the BamHI site of pSEYC68-GAL (Emr et al. 1986) to form p68g-3a. To generate a target vector for Tn3 mutagenesis, we subcloned the 4.4-kb PstI-HindIII fragment of pBS-15a' into PstI-HindIII-linearized pHSS6 (Seifert et al. 1986a), forming pHSS6-15a.

The ABF1 3' deletion series shown in Figure 2 was generated by subcloning fragments of pBS-15a and pHSS6-15a:: Tn3LEU2 into the lacZ gene of Bluescript as follows: The 425-bp EcoRI-StuI fragment from pBS-15a was inserted into EcoRI/ HincII-digested Bluescript to give pBS-15a $\Delta S$; the 1275-bp EcoRI-KpnI fragment from pBS-15a was inserted into EcoRI/ $K p n I$-digested Bluescript to give pBS-15a $\Delta \mathrm{K}_{;}$and the 1729 -bp $E c o R I-E c o R V$ fragment from pBS-15a was inserted into EcoRIEcoRV-digested Bluescript to give pBS-15a $\triangle \mathrm{R}$. We used the SalI site, 58 bp from the end of the Tn $3-L E U 2$ minitransposon (Siefert et al. 1986a), to subclone fragments of the $A B F 1$ gene from the pHSS6-15a:: Tn3-LEU2 insertion mutants. The 735-bp EcoRI-Sall fragment from pHSS6-15a :: Tn3-LEU2-3 was inserted into EcoRI/Sall-digested Bluescript to give pBS-15a $\Delta 3$, and the 2540-bp EcoRI-SalI fragment from pHSS6-15a :: Tn3$L E U 2-2$ was inserted into EcoRI/SalI-digested Bluescript to give $\mathrm{pBS}-15 \mathrm{a} \Delta 2$.

\section{Preparation and use of anti-ABF I antibodies}

ABF I was purified as described previously (Sweder et al. 1988). A 4-lb female New Zealand rabbit was immunized with $50 \mu \mathrm{g}$ of ABF I. Two 25- $\mu \mathrm{g}$ boosts were given 8 and 10 weeks later. Serum was obtained 9-15 days after the final boost.

Mouse monoclonal antibodies against ABF I were raised in $\mathrm{RBF} / \mathrm{Dn}$ mice. A mouse was given three $10-\mu \mathrm{g}$ injections of $\mathrm{ABF}$ I at 2 -week intervals. A final 5 - $\mu$ g boost was given 2 weeks later. Three days after the final boost, the mouse was sacrificed and the spleen cells were fused with HL-1 myeloma cells. Antibody-producing hybridomas were selected on AAT medium [adenine, aminopterin, thymidine (Taggart and Samloff 1983)]. The rabbit polyclonal antiserum and hybridoma culture supernatants were screened for the presence of ABF I antibodies by protein blot and gel retardation assays. Polyclonal antiserum was diluted 1:100 for use in probing protein blots or in screening the $\lambda g t 11$ library. Monoclonal antibody supernatants were diluted $1: 5(6 \mathrm{C} 11 \mathrm{G} 4)$ or used undiluted (2E7E9).

\section{Screening of a $\lambda g t 11$ library}

Antibodies that recognized $E$. coli proteins were removed from the polyclonal antiserum, as described in Johnson et al. (1985). A $\lambda$ gt 11 library of genomic yeast DNA fragments was screened on nitrocellulose filters, as described in Johnson et al. (1985), except that all washes were done in TTBS $[0.1 \%$ Tween 20 in Tris-buffered saline: $50 \mathrm{~mm}$ Tris- $\mathrm{HCl}$ (pH 7.6), $150 \mathrm{mM} \mathrm{NaCl}$, and bound anti-ABF I antibodies were detected with an alkaline phosphatase-conjugated goat anti-rabbit antibody (Bio-Rad). Immune complexes were visualized by development with nitroblue tetrazolium (NBT) and 5-bromo-4-chloro-3-indolyl phosphate (BCIP), as instructed by the supplier (Amersham).

\section{Preparation of extracts and immunoblotting}

Bacterial extracts were made as described by Wiederrecht et al. (1988). E. coli TG-1 transformants containing pBS-15a or its derivatives were grown with or without $10 \mathrm{~mm}$ IPTG to $A_{595}=1.0$ in $5 \mathrm{ml}$ of Luria broth containing ampicillin (100 $\mu \mathrm{g} / \mathrm{ml})$. The cultures were harvested $(6000 \mathrm{~g}, 5 \mathrm{~min})$, and the cell pellets were lysed in $300 \mu \mathrm{l}$ of SDS-gel loading buffer. Following incubation for $10 \mathrm{~min}$ at $90^{\circ} \mathrm{C}$, the lysates were passed twice through a 25 -gauge needle to reduce viscosity. Fifty microliters of lysate was loaded onto a $10 \%$ SDS-polyacrylamide gel. The proteins were separated by electrophoresis and transferred to a nitrocellulose membrane using a trans-blot apparatus (Bio-Rad). Filters were blocked by incubating for $1 \mathrm{hr}$ in $5 \%$ non-fat dry milk in TBS. The filters were then incubated for $1 \mathrm{hr}$ with anti-ABF I polyclonal antiserum or monoclonal antibodies in $5 \%$ non-fat dry milk/TBS. Following three washes in TTBS, the filters were incubated for $1 \mathrm{hr}$ with an alkaline phosphatase-conjugated secondary antibody, washed three times with TTBS, and incubated for 10-30 min with the NBT/BCIP developing reagent. The developing reagent consists of $15 \mathrm{mg}$ NBT (dissolved in $1 \mathrm{ml} 70 \%$ dimethylformamide) and 7.5 $\mathrm{mg} \mathrm{BCIP}$ (dissolved in $1 \mathrm{ml}$ dimethylformamide) per $50 \mathrm{ml}$ of $0.1 \mathrm{M} \mathrm{NaHCO}_{3}$ (pH 9.8), $1 \mathrm{mM} \mathrm{MgCl}$.

Yeast extracts were prepared from $100-\mathrm{ml}$ cultures. After centrifuging $(3000 \mathrm{~g}, 10 \mathrm{~min})$, cells were resuspended in $0.2 \mathrm{ml}$ of buffer A [20 mMM HEPES (pH 7.4), 10\% glycerol, $1 \mathrm{~mm} 2$ mercaptoethanol, $1 \mathrm{mM}$ EDTA, $1 \mathrm{mM}$ phenylmethylsulfonyl fluoride (PMSF)] containing $1 \mathrm{M} \mathrm{KCl}$. Lysis was achieved by vortexing the cells three times for $30 \mathrm{sec}$ in the presence of 0.3 grams of glass beads. The lysate was microfuged for $5 \mathrm{~min}$ and the supernatant saved. An additional $0.2 \mathrm{ml}$ of buffer A containing $1 \mathrm{M} \mathrm{KCl}$ was added to the pellet and the lysate was vortexed three times for $30 \mathrm{sec}$. After centrifugation, the supernatants were combined. In some cases, extracts were desalted against buffer A containing $50 \mathrm{mM} \mathrm{KCl}$, using Centricon- 10 concentrators. Fifty micrograms of extract was electrophoresed on $7.5 \%$ SDS-polyacrylamide gels, and immunoblotting was performed with monoclonal antibodies, as described above.

\section{Tn3 insertion mutagenesis}

The transposon mutagenesis system developed by Seifert et al. (1986a,b) was used to generate LEU2 insertions into the ABF1 gene. The target vector pHSS6-15a contained the $15 \mathrm{a}$ insert, as well as a gene conferring kanamycin resistance $\left(\mathrm{Km}^{\mathrm{r}}\right)$, and was used to transform the RDP146 strain carrying the plasmid pLB101. pLB101 confers chloramphenicol resistance $\left(\mathrm{Cm}^{\mathrm{r}}\right)$ and contains a gene encoding $\mathrm{Tn} 3$ transposase. The resulting $\mathrm{Km}^{\mathrm{r}} \mathrm{Cm}^{\mathrm{r}}$ strain was grown to mid-log phase and mated for 15 min at $37^{\circ} \mathrm{C}$ with the strain RDP146 carrying the plasmid pOX38 ::m-Tn3 (LEU2). The F derivative pOX38 carries a Tn3 minitransposon that confers ampicillin resistance $\left(\mathrm{Ap}^{\mathrm{r}}\right)$ and contains the yeast LEU2 gene. The resulting transconjugate was tested for resistance to ampicillin, kanamycin, and chloramphenicol. This strain was grown overnight at $30^{\circ} \mathrm{C}$ with antibiotics $(50 \mu \mathrm{g} / \mathrm{ml}$ ampicillin, $40 \mu \mathrm{g} / \mathrm{ml}$ kanamycin, and 30 $\mu \mathrm{g} / \mathrm{ml}$ chloramphenicol) to allow transposition of the minitransposon. The overnight culture was diluted into medium without antibiotics and mated with the strain NS2114Sm. This 
streptomycin-resistant $\left(\mathrm{Sm}^{\mathrm{x}}\right)$ strain carries the cre enzyme of bacteriophage $\mathrm{P} 1$ that allows resolution of the Tn3 cointegrant through action at $\operatorname{lox} P$ sites within $\mathrm{m}-\mathrm{Tn} 3$ (LEU2). The desired NS2114Sm transconjugants were selected on L-agar plates containing ampicillin $(50 \mu \mathrm{g} / \mathrm{ml})$, kanamycin $(40 \mu \mathrm{g} / \mathrm{ml})$, and streptomycin $(100 \mu \mathrm{g} / \mathrm{ml})$.

Small-scale plasmid preparations from the NS2114Sm transconjugants were used to transform TG-1 cells to $\mathrm{Km}^{\mathrm{r}}$. This allowed for easier isolation of plasmids containing inserts. Restriction analysis of plasmid DNA from 24 isolates revealed that the sites of $\operatorname{Tn} 3$ insertion were distributed throughout the $15 a$ insert. DNA from five different insertion mutants was digested with NotI, and the 15a :: Tn3-LEU2 fragments were isolated by electroelution. These were used in the fragment-mediated transformation procedure described by Rothstein (1983) to disrupt the $A B F 1$ gene in the yeast strain SEY6210.5.

\section{Hybridization procedures}

A yeast genomic library in the plasmid YEp24 (Carlson and Botstein 1982) was screened by hybridization to the $\lambda \mathrm{gt} 11-15 \mathrm{a}$ insert, using colony hybridization procedures described previously (Hanahan and Meselson 1980; Johnson et al. 1985). Approximately $10^{4} \mathrm{E}$. coli transformants were spread on L-agar plates $(150 \mathrm{~mm})$ containing $100 \mu \mathrm{g} / \mathrm{ml}$ ampicillin and were incubated at $37^{\circ} \mathrm{C}$ for $6 \mathrm{hr}$. The resultant colonies were lifted onto duplicate nitrocellulose filters, grown on fresh L-ampicillin plates for $4 \mathrm{hr}$ at $37^{\circ} \mathrm{C}$, and transferred to plates containing 250 $\mathrm{g} / \mathrm{ml}$ of chloramphenicol for overnight amplification. Cell lysis and hybridization of the 15a probe to the nitrocellulose filters was performed as described by Maniatis et al. (1982). Positive clones were rescreened to obtain single colonies.

Yeast DNA and total cellular RNA were prepared as described previously (Johnson et al. 1985). Poly(A) ${ }^{+}$RNA was purified by oligo( $\mathrm{T}$ )-cellulose chromatography (Collaborative Research), as described in Maniatis et al. (1982). Northern and Southern blot analyses were performed by standard procedures (Maniatis et al. 1982). DNA fragments used as hybridization probes were electroeluted from agarose gels and labeled with $\left[\alpha-{ }^{32} \mathrm{P}\right] \mathrm{dCTP}$, using the random primer method (Feinberg and Vogelstein 1983|. Riboprobes were synthesized from PstI-linearized pBS-15a and pBS-15a' using T7 RNA polymerase and $\left[\alpha^{-32} \mathrm{P}\right] \mathrm{UTP}$, according to methods provided by the supplier (Stratagene).

\section{Other methods}

Double-stranded plasmid DNA sequencing was performed by the dideoxy chain termination method (Sanger et al. 1977), using $\alpha^{-35}$ S-labeled dATP and modified T7 DNA polymerase (Sequenase II, U.S. Biochemicals). Plasmid DNAs were purified from $\mathrm{DH} 5 \alpha \mathrm{F}^{\prime}$ transformants and sequenced by the procedure described in Kraft et al. (1988), except that (1) the DNA was precipitated twice with polyethylene glycol, (2) the DNA was denatured at $85^{\circ} \mathrm{C}$ for $5 \mathrm{~min}$ in $0.2 \mathrm{~N} \mathrm{NaOH}$ and $0.2 \mathrm{mM}$ EDTA, and (3) $10 \%$ dimethylsulfoxide was added to the sequencing reactions. In the cases where insert-specific oligonucleotides were used as primers, the lyophilized oligonucleotide $\langle 0.2$ $\mu$ mole synthesis; Pharmacia Gene Assembler) was resuspended in $1 \mathrm{ml}$ of water, heated to $65^{\circ} \mathrm{C}$ for $30 \mathrm{~min}$ to dissolve the DNA, and microfuged $10 \mathrm{~min}$. The supernatant was diluted $1: 100$ in water, and $1 \mu \mathrm{l}$ of the oligonucleotide was used. Gel retardation assays were performed as described previously (Sweder et al. 1988). The element B oligonucleotide (ABF Ibinding site) used in competition studies was

\section{Acknowledgments}

We thank Carolyn Cabanski for technical assistance. We also thank Caltech's Monoclonal Antibody Facility for generating the monoclonal antibodies used in this study and Dr. Bruce Birren for providing yeast chromosomal DNA blots. We are grateful to Drs. Colin Gordon, Karen Sitney, Scott MoyeRowley, Greg Wiederrecht, and Keith Harshman for providing libraries, plasmids, and strains and for helpful advice. We thank Drs. Rati Verma, Scott Moye-Rowley, and Greg Wiederrecht for critically reading the manuscript. This work was supported by a grant from the National Institutes of Health (GM-25508), a Procter and Gamble postdoctoral fellowship to P.R.R., and the National Institutes of Health (BRSG RR07003).

\section{References}

Abraham, J., K.A. Nasmyth, J.N. Strathern, A.J.S. Klar, and J.B. Hicks. 1984. Regulation of mating type information in yeast. J. Mol. Biol. 176: 307-331.

Amati, B.D. and S.M. Gasser. 1988. Chromosomal ARS and CEN elements bind specifically to the yeast nuclear scaffold. Cell 54: 967-978.

Bender, A. and G.F. Sprague. Jr. 1987. MAT $\alpha 1$ protein, a yeast transcription activator, binds synergistically with a second protein to a set of cell-type-specific genes. Cell 50: 681-691.

Bennetzen, J. and B. Hall. 1981. Codon selection in yeast. $J$. Biol. Chem. 257: 3026-3031.

Berg, J.M. 1986. Potential metal-binding domains in nucleic acid binding proteins. Science 232: 485-487.

Boeke, I.D., F. LaCroute, and G.R. Fink. 1984. A positive selection for mutants lacking orotidine-5'-phosphate decarboxylase activity in yeast: 5-Fluoro-orotic acid resistance. Mol. Gen. Genet. 197: 345-346.

Brand, A.H., L. Breeden, J. Abraham, R. Sternglanz, and K. Nasmyth. 1985. Characterization of a 'silencer' in yeast: A DNA sequence with properties opposite to those of a transcriptional enhancer. Cell 41: 41-48.

Brand, A.H., G. Micklem, and K. Nasmyth. 1987. A yeast silencer contains sequences that can promote autonomous plasmid replication and transcriptional activation. Cell 51: 709-719.

Broach, J.R., Y.-Y. Li, J. Feldman, M. Jayaram, J. Abraham, K.A. Nasmyth, and J.B. Hicks. 1983. Localization and sequence analysis of yeast origins of DNA replication. Cold Spring Harbor Symp. Quant. Biol. 47: 1165-1173.

Brown, R.S., C. Somder, and P. Argos. 1985. The primary structure of transcription factor TFIIIA has 12 consecutive repeats. FEBS Lett. 186: 271-274.

Buchman, A.R., W.J. Kimmerly, J. Rine, and R.D. Kornberg. 1988a. Two DNA-binding factors recognize specific sequences at silencers, upstream activating sequences, autonomously replicating sequences, and telomeres in Saccharomyces cerevisiae. Mol. Cell. Biol. 8: 210-225.

Buchman, A.R., N.F. Lue, and R.D. Kornberg. 1988b. Connections between transcriptional activators, silencers and telomeres as revealed by functional analysis of a yeast DNA binding protein. Mol. Cell. Biol. 8: 5086-5099.

Capieaux, E., M.-L. Vignais, A. Sentenac, and A. Goffeau. 1989. The yeast $\mathrm{H}^{+}$-ATPase gene is controlled by the promoter binding factor TUF. J. Biol. Chem. 264: 7437-7446.

Carlson, M. and D. Botstein. 1982. Two differentially regulated mRNAs with different $5^{\prime}$ ends encode secreted and intracellular forms of yeast invertase. Cell 28: 145-154.

Celniker, S.E., K. Sweder, F. Srienc, J.E. Bailey, and J.L. Campbell. 1984. Deletion mutations affecting autonomously rep- 
licating sequence ARS1 of Saccharomyces cerevisiae. Mol. Cell. Biol. 4: 2455-2466.

Chou, P.Y. and G.P. Fasman. 1977. $\beta$-turns in proteins. I. Mol. Biol. 115: 135-175.

DePamphilis, M.L. 1988. Transcriptional elements as components of eukaryotic origins of DNA replication. Cell 52: 635-638.

Diffley, J.F.X. and B. Stillman. 1988. Purification of a yeast protein that binds to origins of DNA replication and a transcriptional silencer. Proc. Natl. Acad. Sci. 85: 2120-2124.

Dorsman, J.C., W.C. vanHeeswijk, and L.A. Grivell. 1988. Identification of two factors which bind to the upstream sequences of a number of nuclear genes coding for mitochondrial proteins and to genetic elements important for cell division in yeast. Nucleic Acids. Res. 16: 7287-7301.

Dorsman, J.C., M.M. Doorenbosch, C.T.C. Maurer, J.H. deWinde, W.H. Mager, R.J. Planta, and L.A. Grivell. 1989. An ARS/silencer binding factor also activates two ribosomal protein genes in yeast. Nucleic Acids Res. 17: 4917-4923.

Eisenberg, S., C. Civalier, and B.K. Tye. 1988. Specific interaction between a Saccharomyces cerevisiae protein and a DNA element associated with certain autonomously replicating sequences. Proc. Natl. Acad. Sci. 85: 743-746.

Emr, S., A. Vassarotti, J. Garrett, B. Geller, M. Takeda, and M. Douglas. 1986. The amino terminus of the yeast F1-ATPase $\beta$-subunit functions as a mitochondrial import signal. $I$. Cell. Biol. 102: 523-533.

Evans, R.M. and S.M. Hollenberg. 1988. Zinc fingers: Gilt by association. Cell 52: 1-3.

Feinberg, A.P. and B. Vogelstein. 1983. A technique for radiolabeling DNA restriction endonuclease fragments to high specific activity. Anal. Biochem. 132: 6-13.

Feldman, J.B., J.B. Hicks, and J.R. Broach. 1984. Identification of sites required for repression of a silent mating type locus in yeast. J. Mol. Biol. 178: 815-834.

Francesconi, S.C. and S. Eisenberg. 1989. Purification and characterization of OBF1: A Saccharomyces cerevisiae protein that binds to autonomously replicating sequences. Mol. Cell. Biol. 9: 2906-2913.

Giedroc, D.P., K.M. Keating, K.R. Williams, W.H. Konigsberg, and J.E. Coleman. 1986. Gene 32 protein, the singlestranded DNA binding protein from bacteriophage T4, is a zinc metalloprotein. Proc. Natl. Acad. Sci. 83: 8452-8456.

Green, L.M. and J.M. Berg. 1989. A retroviral Cys-Xaa 2 -Cys$\mathrm{Xaa}_{4}-\mathrm{His}-\mathrm{Xaa}_{4}$-Cys peptide binds metal ions: Spectroscopic studies and a proposed three-dimensional structure. Proc. Natl. Acad. Sci. 86: 4047-4051.

Hamil, K.G., H.G. Nam, and H.M. Fried. 1988. Constitutive transcription of yeast ribosomal protein gene TCM1 is promoted by uncommon cis- and trans-acting elements. Mol. Cell. Biol. 8: 4328-4341.

Hanahan, D. and M. Meselson. 1980. Plasmid screening at high colony density. Gene 10: 63-67.

Hoeffer, W.K., R. Kovelman, and R.G. Roeder. 1988. Activation of transcription factor IIIC by the adenovirus E1A protein. Cell 53: 907-920.

Hofmann, J.F.-X., T. Laroche, A.H. Brand, and S.M. Gasser. 1989. RAP-1 factor is necessary for DNA loop formation in vitro at the silencer mating type locus HML. Cell 57: 725737.

Hope, I. and K. Struhl. 1985. GCN4 protein, synthesized in vitro binds HIS3 regulatory sequences: Implications for general control of amino acid biosynthetic genes in yeast. Cell 43: $177-188$.

-1986. Functional dissection of a eukaryotic transcriptional activator protein, GCN4 of yeast. Cell 46: 885-894.
Huet, J. and A. Sentenac. 1987. TUF, the yeast DNA-binding factor specific for $\mathrm{UAS}_{\mathrm{rpg}}$ upstream activating sequences: Identification of the protein and its DNA-binding domain. Proc. Natl. Acad. Sci. 84: 3648-3652.

Jarvis, E.E., D.C. Hagen, and G.F. Sprague. 1988. Identification of a DNA segment that is necessary and sufficient for $\alpha$-specific gene control in Saccharomyces cerevisiae: Implications for regulation of $\alpha$-specific and a-specific genes. Mol. Cell. Biol. 8: 309-320.

Jarvis, E.E., K.L. Clark, and G.F. Sprague, Jr. 1989. The yeast transcription activator PRTF, a homolog of the mammalian serum response factor, is encoded by the MCM1 gene. Genes Dev. 3: 936-945.

Johnson, L.M., M. Snyder, L.M.S. Chang, R.W. Davis, and J.L. Campbell. 1985. Isolation of the gene encoding yeast polymerase I. Cell 43: 368-377.

Jones, E.W. 1977. Proteinase mutants of Saccharomyces cerevisiae. Genetics 85: 23-33.

Jones, K.A., J.T. Kadonaga, P.J. Rosenfield, T.J. Kelly, and R. Tjian. 1987. A cellular DNA-binding protein that activates eukaryotic transcription and DNA replication. Cell 48: 7989.

Kearsey, S. 1984. Structural requirements for the function of a yeast chromosomal replicator. Cell 37: 299-307.

Keleher, C.A., C. Goutte, and A.D. Johnson. 1988. The yeast cell-type specific repressor $\alpha 2$ acts cooperatively with a noncell-type-specific protein. Cell 53: 927-936.

Kimmerly, W.J. and J. Rine. 1987. Replication and segregation of plasmids containing cis-acting regulatory sites of silent mating-type genes in Saccharomyces cerevisiae are controlled by the SIR genes. Mol. Cell. Biol. 7: 4225-4237.

Kimmerly, W., A. Buchman, R. Kornberg, and J. Rine. 1988. Roles of two DNA-binding factors in replication, segregation and transcriptional repression mediated by a yeast silencer. $E M B O$ I. 7: 2241-2253.

Klug, A. and D. Rhodes. 1987. Zinc fingers: A novel protein motif for nucleic acid recognition. Trends Biochem. Sci. 12: 464-469.

Koshland, D., J.C. Kent, and L.H. Hartwell. 1985. Genetic analysis of the mitotic transmission of minichromosomes. Cell 40: 393-403.

Kozak, M. 1983. Comparison of initiation of protein synthesis in prokaryotes, eukaryotes and organelles. Microbiol. Rev. 47: $1-45$.

Kraft, R., J. Tardiff, K.S. Krauter, and L.A. Leinwand. 1988. Using mini-prep plasmid DNA for sequencing double stranded templates with Sequenase. BioTechniques 6: 544547.

Lai, E., B.W. Birren, S.M. Clark, M.I. Simon, and L. Hood. 1989. Pulsed field gel electrophoresis. BioTechniques 7: 34-42.

Landschulz, W.H., P.F. Johnson, and S.L. McKnight. 1988. The leucine zipper: A hypothetical structure common to a new class of DNA binding proteins. Science 240: 1759-1764.

Ma, J. and M. Ptashne. 1987. A new class of yeast transcriptional activators. Cell 51: 113-119.

Maniatis, T., E. Fritsch, and J. Sambrook. 1982. Molecular cloning: A laboratory manual. Cold Spring Harbor Laboratory, Cold Spring Harbor, New York.

Miller, J.H. 1972. Experiments in molecular cloning. Cold Spring Harbor Laboratory, Cold Spring Harbor, New York.

Miller, J., A.D. McLachlam, and A. Klug. 1985. Repetitive zincbinding domains in the protein transcription factor IIIA from Xenopus oocytes. EMBO f. 4: 1609-1614.

Mitchell, P.J. and R. Tjian. 1989. Transcriptional regulation in mammalian cells by sequence-specific DNA binding proteins. Science 245: 371-378. 
Moye-Rowley, W.S., K.D. Harshman, and C.S. Parker. 1989. Yeast YAP1 encodes a novel form of the jun family of transcriptional activator proteins. Genes Dev. 3: 283-292.

Nagata, K., R.A. Guggenheimer, T. Enomoto, J.H. Lichy, and J. Hurwitz. 1982. Adenovirus DNA replication in vitro: Identification of a host factor that stimulates synthesis of the preterminal protein-dCMP complex. Proc. Natl. Acad. Sci. 79: $6438-6442$.

Newlon, C.S. 1989. Yeast chromosome replication and segregation. Microbiol. Rev. 52: 568-510.

Pabo, C.O. and R.T. Sauer. 1984. Protein-DNA recognition. Annu. Rev. Biochem. 53: 293-321.

Palzkill, T.G., S.G. Oliver, and C.S. Newlon. 1986. DNA sequence analysis of ARS elements from chromosome III of Saccharomyces cerevisiae: Identification of a new conserved sequence. Nucleic Acids Res. 14: 6247-6264.

Palzkill, T.G. and C.S. Newlon. 1988. A yeast replication origin consists of multiple copies of a small conserved sequence. Cell 43: 441-450.

Passmore, S., R. Elble, and B.K. Tye. 1989. A protein involved in minichromosome maintenance in yeast binds a transcriptional enhancer conserved in eukaryotes. Genes Dev, 3: 921-935.

Rawlins, D.R., P.J. Rosenfeld, R.J. Wides, M.D. Challberg, and T.J. Kelly, Jr. 1984. Structure and function of the adenovirus origin or replication. Cell 37: 309-319.

Rothstein, R. 1983. One-step disruption in yeast. Methods Enzymol. 101: 202-211.

Sanger, R., S. Nicklen, and A. Coulson. 1977. DNA sequencing with chain-terminating inhibitors. Proc. Natl. Acad. Sci. 74: 5463-5467.

Santoro, C., N. Mermod, P.C. Andrew, and R. Tjian. 1988. A family of human CCAAT-block-binding proteins active in transcription and DNA replication: Cloning and expression of multiple cDNAs. Nature 334: 218-224.

Seifert, H.S., M. So, and F. Heffron. 1986a. Shuttle mutagenesis: A method of introducing transposons into transformable organisms. In Genetic engineering: Principle and methods (ed. J.K. Setlow and A. Hollaender). Plenum Press, New York.

Seifert, H.S., E. Chen, M. So, and F. Heffron. 1986b. Shuttle mutagenesis: A method of transposon mutagenesis for Saccharomyces cerevisiae. Proc. Natl. Acad. Sci. 83: 735-739.

Sherman, F., G.R. Fink, and J. Hinks. 1979. Methods in yeast genetics. Cold Spring Harbor Laboratory, Cold Spring Harbor, New York.

Shore, D. and K. Nasmyth. 1987. Purification and cloning of a DNA binding protein from yeast that binds to both silencer and activator elements. Cell 51: 721-732.

Shore, D., D.J. Stillman, A.H. Brand, and K.A. Nasmyth. 1987. Identification of silencer binding proteins from yeast: Possible roles in $S I R$ control and DNA replication. EMBO $I$. 6: $461-467$.

Snyder, M., A.R. Buchman, and R.W. Davis. 1987. Bent DNA at a yeast autonomously replicating sequence. Nature 324: $87-89$.

Sorger, P.K., M.J. Lewis, and H.R.B. Pelham. 1987. Heat shock factor is regulated differently in yeast and HeLa cells. $\mathrm{Na}$ ture 329: 81-84.

Sorger, P.K. and H.R.B. Pelham. 1988. Yeast heat shock factor is an essential DNA-binding protein that exhibits temperature-dependent phosphorylation. Cell 54: 855-864.

Srienc, F., J.E. Bailey, and J.L. Campbell. 1985. Effect of ARS1 mutations on chromosome stability in Saccharomyces cerevisiae. Mol. Cell. Biol. 5: 1676-1684.

Stanway, C., J. Mellor, J.E. Ogden, A.J. Kingsman, and S.M. Kingsman. 1987. The UAS of the yeast PGK gene contains functionally distinct domains. Nucleic Acids Res. 15: 6855-6873.

Stinchcomb, D.T., C. Mann, E. Selker, and R.W. Davis. 1981. DNA sequences that allow the replication and segregation of yeast chromosomes. ICN-UCLA Symp. 22: 473-488.

Strich, R.M., M. Wootner, and J.F. Scott. 1986. Mutations in ARSI increase the rate of simple loss of plasmids in Saccharomyces cerevisiae. Yeast 2: 169-178.

Sweder, K.S., P.R. Rhode, and J.L. Campbell. 1988. Purification and characterization of proteins that bind to yeast ARSs. I. Biol. Chem. 263: 17270-17277.

Taggart, R. and I. Samloff. 1983. Stable antibody-producing murine hybridomas. Science 219: 1228-1230.

Umek, R.M. and D. Kowalski. 1987. Yeast regulatory sequences preferentially adopt a non-B conformation in supercoiled DNA. Nucleic Acids Res. 15: 4467-4480.

Vignais, M.L., L.P. Woudt, G.M. Wassenaar, W.H. Mager, A. Sentenac, and R.J. Planta. 1987. Specific binding of TUF factor to upstream activation sites of yeast ribosomal protein genes. $E M B O$ \%. 6: 1451-1457.

Walker, S.S., S.C. Francesconi, B.K. Tye, and S. Eisenberg. 1989. The OBFl protein and its DNA-binding site are important for the function of an autonomously replicating sequence in Saccharomyces cerevisiae. Mol. Cell. Biol. 9: 2914-2921.

Wiederrecht, G., D. Seta, and C.S. Parker. 1988. The isolation of the gene encoding the $S$. cerevisiae heat shock transcription factor. Cell 54: 841-853.

Williams, J.S., T.T. Eckdahl, and J.N. Anderson. 1988. Bent DNA functions as a replication enhancer in Saccharomyces cerevisiae. Mol. Cell. Biol. 8: 2763-2769.

Young, R. and R. Davis. 1983. Efficient isolation of genes by using antibody probes. Proc. Natl. Acad. Sci. 80: 11941198. 


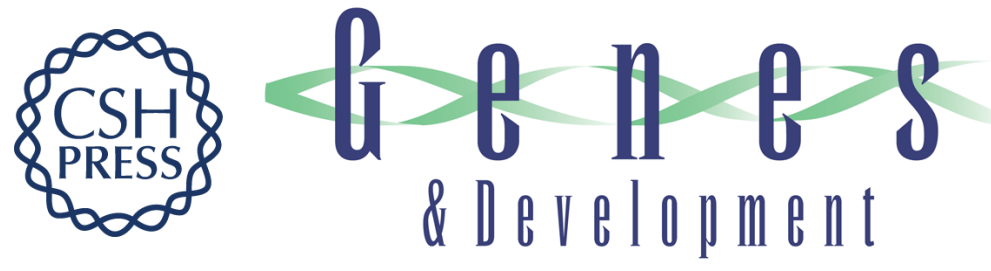

\section{The gene encoding ARS-binding factor I is essential for the viability of yeast.}

P R Rhode, K S Sweder, K F Oegema, et al.

Genes Dev. 1989, 3:

Access the most recent version at doi:10.1101/gad.3.12a.1926

References This article cites 78 articles, 29 of which can be accessed free at:

http://genesdev.cshlp.org/content/3/12a/1926.full.html\#ref-list-1

License

Email Alerting

Service

Receive free email alerts when new articles cite this article - sign up in the box at the top right corner of the article or click here.

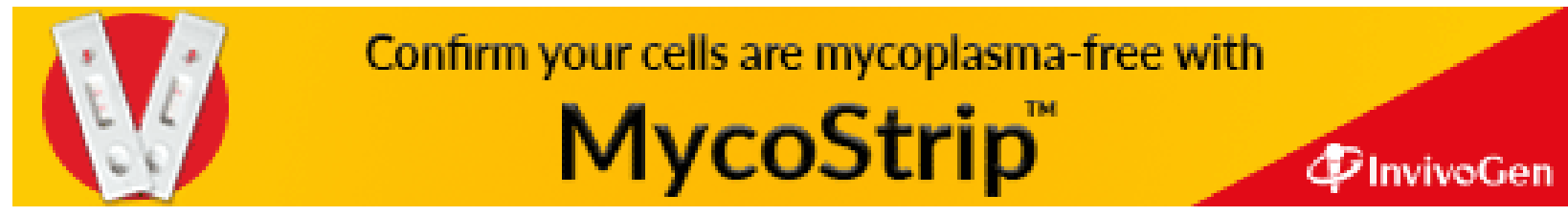

